\title{
IN VITRO INDUCTION OF CALLUS FROM COTYLEDON AND HYPOCOTYL EXPLANTS OF Glycine wightii (Wight \& Arn.) Verdc.
}

\author{
ANDRÉ LUIS COELHO DA SILVA ${ }^{1}$ \\ CECÍLIA SULZBACHER CARUSO ${ }^{2}$ \\ RENATO DE AZEVEDO MOREIRA ${ }^{3}$ \\ ANA CECÍLIA GÓES HORTA ${ }^{4}$
}

\begin{abstract}
With the objective to promote in vitro callus induction, cotyledon and hypocotyl segments of "perennial soybean" (Glycine wightii (Wight \& Arn.) Verdc.) were inoculated in basal medium MS supplemented with sucrose $(1.5$ e $3 \%)$ and $0.8 \%$ agar and different concentrations of 2,4dichlorophenoxyacetic acid (2,4-D) and 6furfurylaminopurine (kinetin). The explants were maintained in a dark growth room at $28^{\circ} \mathrm{C}$. The best callus induction was observed in explants (cotyledon and hypocotyl) maintained in medium containing the combination of 2,4-D (1 mg. $\left.\mathrm{L}^{-1}\right)$, kinetin $\left(0.1 \mathrm{mg} . \mathrm{L}^{-1}\right)$ and $3 \%$ sucrose. To promote callus subculture, the MS
\end{abstract}

medium was supplemented with different combinations of 2,4-D (0.5 to $\left.4.0 \mathrm{mg} . \mathrm{L}^{-1}\right)$, with or without kinetin $\left(0.1 \mathrm{mg} . \mathrm{L}^{-1}\right)$ and sucrose $(1.5$ e $3 \%)$. The calli were maintained 35 days in a dark growth room at $28^{\circ} \mathrm{C}$. The results indicated that the use of 2,4-D $1.0 \mathrm{mg} . \mathrm{L}^{-1}+$ kinetin $0.1 \mathrm{mg} . \mathrm{L}^{-1}+$ sucrose $3 \%$ provided the highest average weight of cotyledons calli fresh matter, whereas the use of 2,4-D $2.0 \mathrm{mg} . \mathrm{L}^{-1}+$ kinetin $0.1 \mathrm{mg} . \mathrm{L}^{-}$ ${ }^{1}+$ sucrose $3 \%$ provided the highest average weight of hypocotyl calli fresh matter. High concentrations of 2,4-D, independent of kinetin and sucrose concentrations, promoted oxidation and reduction in fresh weight from calli of cotyledon and hypocotyls.

INDEX TERMS: Glycine wightii, leguminosae, callogenesis, tissue culture.

\section{INDUÇÃO IN VITRO DE CALOS EM EXPLANTES DE COTILÉDONES E HIPOCÓTILOS DE Glycine wightii (Wight \& Arn.) Verdc.}

RESUMO - Com o objetivo de promover a indução in
vitro de calos, segmentos cotiledonares e de hipocótilos
de plântulas de "soja perene" (Glycine wightii (Wight
\& Arn.) Verdc.) foram inoculados em meio básico MS
contendo diferentes concentrações a diferentes de ácido
2,4-diclorofenoxiacético ( $2,4-\mathrm{D})$ e 6 -furfurilaminopurina
(cinetina), suplementado com sacarose (1,5 e 3\%) e
$0,8 \%$ de agar. Os explantes foram mantidos na ausên-
cia de luz, em sala de crescimento, com a temperatura
de $28^{\circ} \mathrm{C}$. A melhor indução de calos (em cotilédones e
hipocótilos) foi observada em explantes inoculados em
meio contendo $2,4-\mathrm{D}\left(1,0\right.$ mg. L $\left.^{-1}\right)$, cinetina ( 0,1 mg. $\left.\mathrm{L}^{-1}\right)$
e $3 \%$ de sacarose. Para promover o subcultivo de calos
produzidos, foram utilizadas diferentes concentrações de 2,4-D (0,5 a 4,0 mg. $\left.\mathrm{L}^{-1}\right)$, com e sem cinetina $(0,1$ mg. $\left.\mathrm{L}^{-1}\right)$, acrescentando-se sacarose $(1,5$ e $3 \%)$. Os calos foram mantidos por 25 dias na ausência de luz, em sala de crescimento com temperatura de $28^{\circ} \mathrm{C}$. Os resultados indicaram que a combinação de 2,4-D 1,0 mg. $\mathrm{L}^{-1}+$ cinetina $0,1 \mathrm{mg} \cdot \mathrm{L}^{-1}+$ sacarose $3 \%$ proporcionou a maior média de peso de matéria fresca de calos cotiledonares, enquanto que a combinação de 2,4-D 2,0 mg. $\mathrm{L}^{-1}+$ cinetina $0,1 \mathrm{mg} . \mathrm{L}^{-1}+$ sacarose $3 \%$ proporcionou a maior média de peso de matéria fresca de calos de hipocótilos. Altas concentrações de 2,4-D independentes das concentrações de cinetina e sacarose, promoveram oxidação e diminuição no peso fresco dos calos de cotilédones e de hipocótilos.

TERMOS PARA INDEXAÇÃO: Glycine wightii, leguminosae, calogênese, cultura de tecidos.

\footnotetext{
1. Engenheiro Agrônomo, MSc., Grupo de Biofísica Molecular e Espectroscopia/USP-IFSC, Caixa Postal 369, 13560-970, São Carlos, SP, alcoelho@if.sc.usp.br.

2. Dra., USP-IFSC, Caixa Postal 369, 13560-970, São Carlos, SP.

3. Professor Titular, Dr., LABLEC-DBBM/UFC, Caixa Postal 6020, 60451-970, Fortaleza, CE.

4. Professor Adjunto, Dra., LABLEC-DBBM/UFC.
} 


\section{INTRODUCTION}

Glycine wightii (Wight \& Arn.) Verdc. is an important specie belonging to the Leguminosae family, sub-family Papilionoideae, genus Glycine and subgenus Bracteata. It is a perennial creeper plant, native of the South Africa and of the Southwest Asia, generally used for erosion control. In Brazil this plant is known as "perennial soybean".

Among the several applications of the tissue culture, we should emphasize that it is a valuable tool to study the metabolism, physiology and development of plants with specific properties, such as, accumulation of active substances of interest (ROUT et al., 2000; DORAN, 2000).

Research with calli formed from fragments of stems, leaves and roots is mainly carried out to determine the culture conditions required by the explants to survive and grow (SAMOYLOV et al., 1998), to study cell development (LITTLE et al., 2000), to exploit products coming from the primary and secondary metabolism and to obtain cell suspension in propagation (ROUT et al., 2000).

The nutritional requirements necessary for the growth of a tissue in in vitro conditions vary for different species, variety and even between different parts of the plant. So, it is necessary to optimize the culture means (NAGAO et al., 1994). However, there is no standard formulation for this optimization, but the MS medium (MURASHIGE and SKOOG, 1962), with its modifications and dilutions, has presented satisfactory results for several species (ROUT and DAS, 1997).

The production of callus depends mainly on the determination of an adequate balance of growth regulators. However, this balance varies largely in relation to the explant type and to the plant species under investigation. The manipulation of the appropriate levels of auxins and cytokinins is crucial to define the balance of growth regulators so that there is induction of callus formation in the different types of explant (FRANKLIN and DIXON, 1994).

The objective of this work was to promote the in vitro establishment of the "perennial soybean" (Glycine wightii), through the induction and formation of callus, using segments of cotyledons and of hypocotyls as explants, as well as identifying the most adequate medium for the subcultive of formed callus.

\section{MATERIALS AND METHODS}

The experiments were carried out in the Laboratory of Lectins and Glycoconjugates (LABLEC), Department of Biochemistry and Molecular Biology (Federal University of Ceará). Glycine wightii seeds, collected in the city of São Carlos-SP (Brazil) were submitted to the treatment of chemical scarification for 10 min with sulfuric acid (98\%) to break the latency. After that, they were washed with sterile distilled water and left to germinate in Petri plates, under dark conditions, at $28{ }^{\circ} \mathrm{C}$ in the germination chamber. After 7 days, the seedlings were moved and sterilized with NaClO $2.5 \%$ for 15 minutes, and then washed with sterile distilled water.

\section{Induction of the callogenesis}

Segments of cotyledons and hypocotyls with an approximate size of $18 \pm 2 \mathrm{~mm}$ were used as explants. The explants were inoculated in a basal medium MS (MURASHIGE and SKOOG, 1962) containing different concentrations of the growth regulators $(2,4-\mathrm{D}$ and kinetin) and of sucrose according to the treatments: 1) medium without regulators and without sucrose (control); 2) medium without growth regulators with sucrose $1.5 \% ; 3$ ) medium without growth regulators with sucrose $3 \%$; 4) medium with kinetin $0.1 \mathrm{mg} . \mathrm{L}^{-1}$ without sucrose; 5) medium with kinetin $0.1 \mathrm{mg} . \mathrm{L}^{-1}+\mathrm{su}-$ crose $1.5 \%$; 6) medium with kinetin $0.1 \mathrm{mg} . \mathrm{L}^{-1}+\mathrm{su}-$ crose $3 \%$; 7) medium with 2,4-D $0.5 \mathrm{mg} . \mathrm{L}^{-1}$ without sucrose; 8) medium with of 2,4-D $0.1 \mathrm{mg} . \mathrm{L}^{-1}+$ sucrose $1.5 \%$; 9) medium with 2,4-D $0.1 \mathrm{mg} . \mathrm{L}^{-1}+$ sucrose 3 $\%$; 10) medium with $2,4-\mathrm{D} 0.5 \mathrm{mg} . \mathrm{L}^{-1}+$ kinetin 0.1 mg. $\mathrm{L}^{-1}$ without sucrose; 11) medium with $2,4-\mathrm{D} 0.5$ mg. $\mathrm{L}^{-1}+$ kinetin $0.1 \mathrm{mg} . \mathrm{L}^{-1}+$ sucrose $1.5 \%$; 12) medium with 2,4-D $0.5 \mathrm{mg} . \mathrm{L}^{-1}+$ kinetin $0.1 \mathrm{mg} . \mathrm{L}^{-1}+$ sucrose $3 \%$; 13) medium with 2,4-D $0.5 \mathrm{mg} . \mathrm{L}^{-1}+$ kinetin $0.5 \mathrm{mg} . \mathrm{L}^{-1}$ without sucrose; 14) medium with 2,4-D 0.5 mg. $\mathrm{L}^{-1}+$ kinetin $0.5 \mathrm{mg} . \mathrm{L}^{-1}+$ sucrose $1.5 \%$; 15) medium with 2,4-D $0.5 \mathrm{mg} . \mathrm{L}^{-1}+$ kinetin $0.5 \mathrm{mg} . \mathrm{L}^{-1}+$ sucrose $3 \%$; 16) medium with 2,4-D 1.0 mg. $\mathrm{L}^{-1}+$ kinetin $0.1 \mathrm{mg} . \mathrm{L}^{-1}$ without sucrose; 17) medium with $2,4-\mathrm{D} 1.0$ mg. $\mathrm{L}^{-1}+$ kinetin $0.1 \mathrm{mg} . \mathrm{L}^{-1}+$ sucrose $1.5 \%$; 18) medium with $2,4-\mathrm{D} 1.0 \mathrm{mg} . \mathrm{L}^{-1}+$ kinetin $0.1 \mathrm{mg} \cdot \mathrm{L}^{-1}+\mathrm{su}-$ crose $3 \%$; 19) medium with 2,4-D 1.0 mg. $\mathrm{L}^{-1}+$ kinetin 0.5 mg. $\mathrm{L}^{-1}$ without sucrose; 20) medium with $2,4-\mathrm{D} 1.0$ mg. $\mathrm{L}^{-1}+$ kinetin $0.5 \mathrm{mg} . \mathrm{L}^{-1}+$ sucrose $1.5 \%$; 21) medium with 2,4-D $1.0 \mathrm{mg} . \mathrm{L}^{-1}+$ kinetin $0.5 \mathrm{mg} . \mathrm{L}^{-1}+\mathrm{su}-$ crose $3 \%$. The culture media were solidified with 8.0 g. $\mathrm{L}^{-1}$ agar (Merk), the final $\mathrm{pH}$ being adjusted to 5.8.

Ciênc. agrotec., Lavras. V.27, n.6, p.1277-1284, nov./dez., 2003 
The sterilization was performed in autoclave, at $121^{\circ} \mathrm{C}$ for 15 minutes.

The experiments were completely randomized with 21 treatments, 5 replications per treatment, and 25 explants per replication. After 35 days, a visual evaluation was made, in which the formation of callus, coloration and oxidation degree were observed. The results were submitted to the analysis of variance and the mean values of percentages of the formed callus were compared using the Tukey's test at the $5 \%$ level of significance.

\section{Subculture of the callus.}

The calli obtained from cotyledons of hypocotyls (from the culture means that were more efficient in the induction of callus) were divided and inoculated in means supplemented with different concentrations of 2,4-D $\left(0.5 ; 1.0 ; 2.0\right.$ and $\left.4.0 \mathrm{mg} . \mathrm{L}^{-1}\right)$, of kinetin $(0$ and $\left.0.1 \mathrm{mg} . \mathrm{L}^{-1}\right)$ and of sucrose $(1.5$ and $3 \%)$, with the objective of determining the influence of growth regulators and of sucrose on the maintenance and development of the calli. The basal medium used was the MS (MURASHIGE and SKOOG, 1962) containing 8.0 g.L ${ }^{1}$ of agar (Merk), the final $\mathrm{pH}$ being adjusted to 5.8 , before the autoclave was used. For five weeks, the following points were evaluated: growth (fresh matter), morphology and habituation (capacity of the callus to continue growing) of the cotyledons and hypocotyls callus. The completely randomized experiment was conducted in the darkness, at $28^{\circ} \mathrm{C}$. There were 16 treatments with 4 replications, with 5 fragments of callus in each treatment. The results were submitted to the analysis of variance and the mean values of fresh matter were compared by using the Tukey's test at the of 5\% level of significance.

\section{RESULTS AND DISCUSSION}

\section{Induction of the callogenesis}

The production of callus was observed in almost all treatments, except for treatments 1 to 3 which composition did not contain 2,4-D and kinetin, and for treatment 4, which did not contain 2,4-D and sucrose (tables 1 and 2). Treatments 5 and 6, which contained only cytokinin and sucrose, were able to induce the formation of callus. The only difference between these treatments and the treatment 4 was the presence of sucrose and this can be an indication that the addition of only kinetin to the MS basal medium is not enough to induce the formation of callus in cotyledons or in hypocotyls of G. wightii. The cells and tissues of plants cultured in vitro are all practically heterotrophic (PASQUAL et al., 1998), a fact that may be another explanation for the no formation of callus. Besides the hormonal stimulus to induce the beginning of the cell multiplication and the resulting formation of callus, it is necessary the incorporation of a external source providing energy, rich in structures containing carbon, in this case sucrose, necessary for the formation of the framework of cell macromolecules. However, this last possibility is more likely to occur when there is the establishment and maintenance of calli, and not exactly in the callogenesis induction, since the treatments $7,10,13,16$ and 19 , which did not contain sucrose, were capable to induce the formation of calli. That confirms the results obtained with other species of the genus Glycine, in which the appropriate levels of 2,4-D and the cytokinin, either isolated or interacting with each other, are able to induce the formation of calli. Also, the new cells produced in the callus would probably use minerals and other source of carbon other than sucrose, contained in the MS basal medium and in the agar (FRANKLIN and DIXON, 1994).

The addition of the regulators 2,4-D and/or cytokinin to the MS culture basal medium seems to be essential for the induction of callus of $G$. wightii, regarless their source (cotyledons or hypocotyls), as it can be observed for the treatments from 7 to 21 , where all of them produced callus in cotyledons as well as in hypocotyls. In some cases, the use of sucrose did not seem to be an essential condition for the production of calli of G. wightii as it was observed for the treatments 7,10 , 13,16 and 19 .

The most adequate levels of the components of the MS basal medium, modified for the formation of callus in cotyledons and hypocotyls were: 2,4-D 1.0 mg. $\mathrm{L}^{-1}$, kinetin $0.1 \mathrm{mg} . \mathrm{L}^{-1}$ of and sucrose $3 \%$, used in the treatment 18 .

Among the regulators added to the medium, the 2,4-D is known as the main synthetic auxin used to induce the callogenesis, because one of its main characteristics is the capacity to efficiently stimulate the cell division in tissues of several plants (GEORGE, 1996). To induce the growth of callus in explants of dicotyledonous plants, a cytokinin is frequently added to the medium in addition to an auxin. In some cases the 2,4dichlorophenoxyacetic acid can be used separated from other hormones, like the cytokinins, to induce the for- 
mation of callus (GASPAR et al., 1996). According to Pasqual et al. (1998), for the induction of callus in plants of wide leaves, the 2,4-D is generally used in levels between $4.5 \mathrm{mM}-13.6 \mathrm{mM}\left(1.0-3.0 \mathrm{mg} . \mathrm{L}^{-1}\right)$. In spite of 2,4-D be one of the most important factors in the process of stimulating the cell division, it is also important to observe the interactive effects that can happen with other hormones.

The optimum level of sucrose to induce morphogenesis or cell growth differs among genotypes, but is generally between 2 and $4 \%$ (PASQUAL et al., 1998). In the case of $G$. wightii it was found an optimum concentration of $3 \%$, thus confirming the results obtained in other works related to the induction of the callogenesis.
Several formulations of medium have been used in the in vitro cultures. According to Bertolucci (2000), the basal medium MS is the most used in tissue cultures. In the case of soybean, this medium is used mostly for the induction of callogenesis and of somatic embryogenesis, but there are examples of modifications, yielting optimization with consequent increase in the amount of formed callus (SAMOYLOV et al., 1998). The results presented in this stage of the work demonstrated, therefore, the optimisation of the basal medium MS for the formation of callus of $G$. wightii, by the addition of 2,4-D, kinetin and sucrose at the levels of $1.0 \mathrm{mg} . \mathrm{L}^{-1}, 0.1 \mathrm{mg} . \mathrm{L}^{-1}$ and $3 \%$, respectively.

TABLE 1 - Percentages of calli obtained in treatments used for induction of callogenesis in cotyledons of $G$. wigthii in relation to different concentrations of 2,4-D, kinetin and sucrose.

\begin{tabular}{ccccc}
\hline Treatment & 2,4-D $\left(\mathbf{m g} . \mathbf{L}^{-\mathbf{1}}\right)$ & Kinetin $\left(\mathbf{m g} \cdot \mathbf{L}^{\mathbf{- 1}}\right)$ & Sucrose $(\boldsymbol{\%})$ & Mean values of induced callus (\%) \\
\hline 18 & 1.0 & 0.1 & 3.0 & $83.2 \mathrm{a}$ * \\
12 & 0.5 & 01 & 3.0 & $60.8 \mathrm{~b}$ \\
15 & 0.5 & 0.5 & 3.0 & $50.4 \mathrm{c}$ \\
9 & 05 & 0.0 & 3.0 & $42.4 \mathrm{~d}$ \\
21 & 1.0 & 0.5 & 3.0 & $33.6 \mathrm{e}$ \\
17 & 1.0 & 0.1 & 1.5 & $30.4 \mathrm{ef}$ \\
11 & 0.5 & 0.1 & 1.5 & $30.4 \mathrm{ef}$ \\
6 & 0.0 & 0.1 & 3.0 & $26.4 \mathrm{fg}$ \\
14 & 0.5 & 0.5 & 1.5 & $22.4 \mathrm{gh}$ \\
8 & 0.5 & 0.0 & 1.5 & $20.0 \mathrm{~h}$ \\
5 & 0.0 & 0.1 & 1.5 & $20.0 \mathrm{~h}$ \\
20 & 1.0 & 0.5 & 1.5 & $13.6 \mathrm{i}$ \\
16 & 1.0 & 0.1 & 0.0 & $6.4 \mathrm{j}$ \\
10 & 0.5 & 0.1 & 0.0 & $6.4 \mathrm{j}$ \\
19 & 1.0 & 0.5 & 0.0 & $3.2 \mathrm{jk}$ \\
13 & 0.5 & 0.5 & 0.0 & $3.2 \mathrm{jk}$ \\
7 & 0.5 & 0.0 & 0.0 & $3.2 \mathrm{jk}$ \\
1 & 0.0 & 0.0 & 0.0 & $0.0 \mathrm{k}$ \\
2 & 0.0 & 0.0 & 1.5 & $0.0 \mathrm{k}$ \\
3 & 0.0 & 0.0 & 3.0 & $0.0 \mathrm{k}$ \\
4 & 0.0 & 0.1 & 0.0 & $0.0 \mathrm{k}$ \\
\hline
\end{tabular}

LDS = Low Difference Significant $5 \%=4.53$

*Mean values followed by the same letter do not differ significantly by the Tukey's test $(p<0.05)$. 
TABLE 2 - Percentages of calli obtained in treatments used for induction of callogenesis em hypocotyls of $G$. wigthii in relation to different concentrations of 2,4-D, kinetin and sucrose.

\begin{tabular}{|c|c|c|c|c|}
\hline Treatment & 2,4-D (mg.L $\left.{ }^{-1}\right)$ & Kinetin (mg.L $\mathbf{L}^{-1}$ ) & Sucrose $(\%)$ & Mean values of induced callus (\%) \\
\hline 18 & 1.0 & 0.1 & 3.0 & $86.4 \mathrm{a}^{*}$ \\
\hline 15 & 0.5 & 0.5 & 3.0 & $42.4 \mathrm{~b}$ \\
\hline 17 & 1.0 & 0.1 & 1.5 & $30.4 \mathrm{c}$ \\
\hline 12 & 0.5 & 0.1 & 3.0 & $30.4 \mathrm{c}$ \\
\hline 9 & 0.5 & 0.0 & 3.0 & $26.4 \mathrm{~cd}$ \\
\hline 14 & 0.5 & 0.5 & 1.5 & $22.4 \mathrm{de}$ \\
\hline 8 & 0.5 & 0.0 & 1.5 & $20.0 \mathrm{e}$ \\
\hline 21 & 1.0 & 0.5 & 3.0 & $20.0 \mathrm{e}$ \\
\hline 6 & 0.0 & 0.1 & 3.0 & $13.6 \mathrm{f}$ \\
\hline 20 & 1.5 & 0.5 & 1.5 & $13.6 \mathrm{f}$ \\
\hline 5 & 0.0 & 0.1 & 1.5 & $10.4 \mathrm{fg}$ \\
\hline 11 & 0.5 & 0.1 & 1.5 & $10.0 \mathrm{fg}$ \\
\hline 16 & 1.0 & 0.1 & 0.0 & $6.4 \mathrm{gh}$ \\
\hline 19 & 1.0 & 0.5 & 0.0 & $3.2 \mathrm{hi}$ \\
\hline 13 & 0.5 & 0.5 & 0.0 & $3.2 \mathrm{hi}$ \\
\hline 10 & 0.5 & 0.1 & 0.0 & $3.2 \mathrm{hi}$ \\
\hline 7 & 0.5 & 0.0 & 0.0 & $3.2 \mathrm{hi}$ \\
\hline 1 & 0.0 & 0.0 & 0.0 & $0.0 \mathrm{i}$ \\
\hline 2 & 0.0 & 0.0 & 1.5 & $0.0 \mathrm{i}$ \\
\hline 3 & 0.0 & 0.0 & 3.0 & $0.0 \mathrm{i}$ \\
\hline 4 & 0.0 & 0.1 & 0.0 & $0.0 \mathrm{i}$ \\
\hline
\end{tabular}

LDS = Low Difference Significant $5 \%=5.43$

* Mean values followed by the same letter do not differ significantly by the Tukey's test $(\mathbf{p}<0.05)$.

\section{Subculture of the callus}

The calli obtained from cotyledons, subcultured in the means containing $1.0 \mathrm{mg} . \mathrm{L}^{-1}$ of $2,4-\mathrm{D}$, presented the largest mean values of fresh matter, independent of the used concentrations of kinetin and of sucrose. The smallest mean values were observed in the treatments containing $4.0 \mathrm{mg} . \mathrm{L}^{-1}$ of 2,4-D (figure 1). It was also observed that, in these treatments, the calli presented dark brown coloration and hardened consistency, differently from the calli obtained from the media containing 1.0 $\mathrm{mg} . \mathrm{L}^{-1}$ of 2,4-D, which presented whitish coloration, friable consistency and diameter of $\sim 1.3 \mathrm{~cm}$ (Figure $3)$.
The concentrations of $3 \%$ of sucrose and 0.1 mg. $\mathrm{L}^{-1}$ of kinetin, independent of the used concentrations of 2,4-D, caused an increment in the weight of the calli, during the period of subcultive.

Regarding the subcultive of hypocotyl callus, the medium supplemented with 2,4-D $2.0 \mathrm{~m}, \mathrm{~g} . \mathrm{L}^{-1}$, kinetin $0.1 \mathrm{mg} . \mathrm{L}^{-1}$ of and sucrose $3 \%$ presented the largest mean value of fresh matter (figure 2 ). All the other medium containing 2.0 or $4.0 \mathrm{mg} . \mathrm{L}^{-1}$ of $2,4-\mathrm{D}$, presented lower mean values than the other tested media. As can be observed in figures 1,2 and 3, the high concentration of 2,4-D (4.0 mg. $\left.\mathrm{L}^{-1}\right)$ affected the development of the callus in a negative way, delaying the growth and promoting the darkening of the cotyledons and hypocotyls calli. 


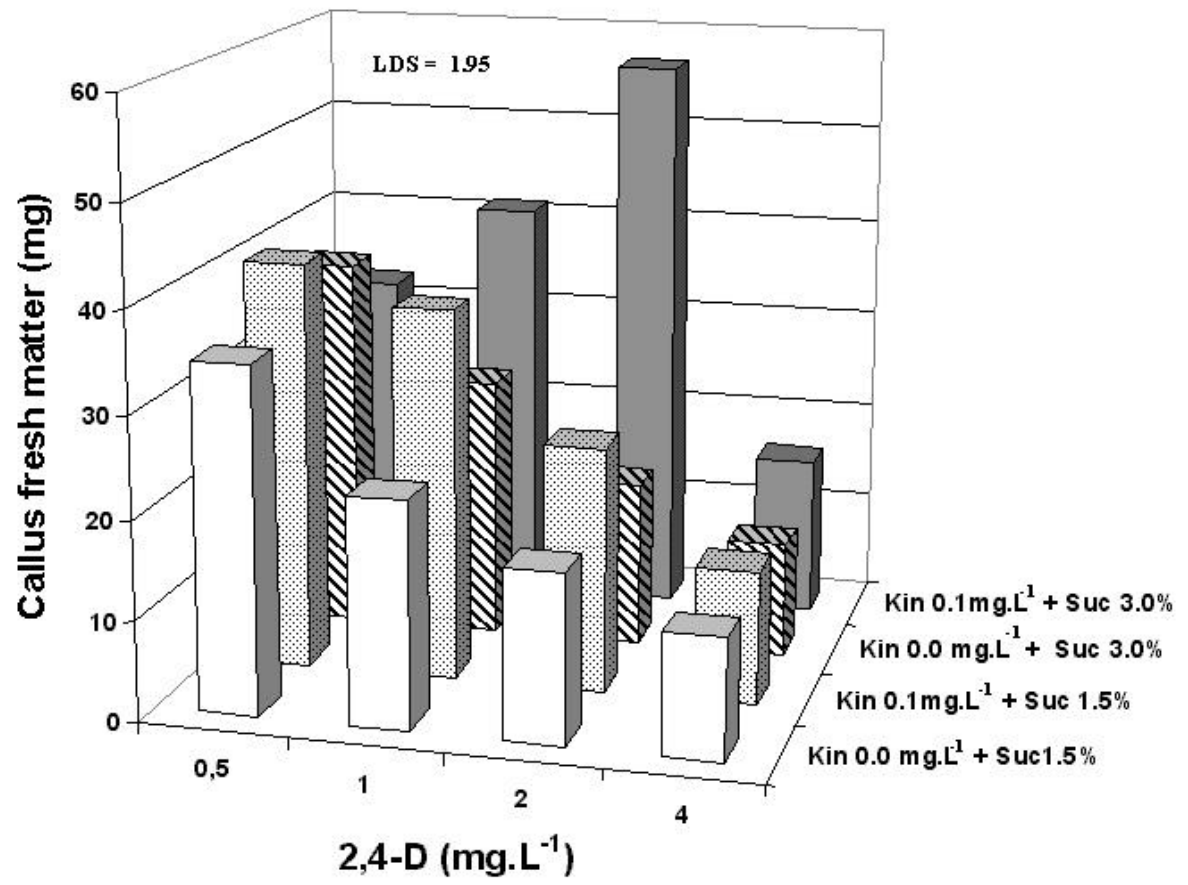

FIGURE 1 - Means of fresh matter of cotyledon calli subcultived in medium with differents concentration of 2,4$\mathrm{D}$, kinetin (Kin) and sucrose (Suc).

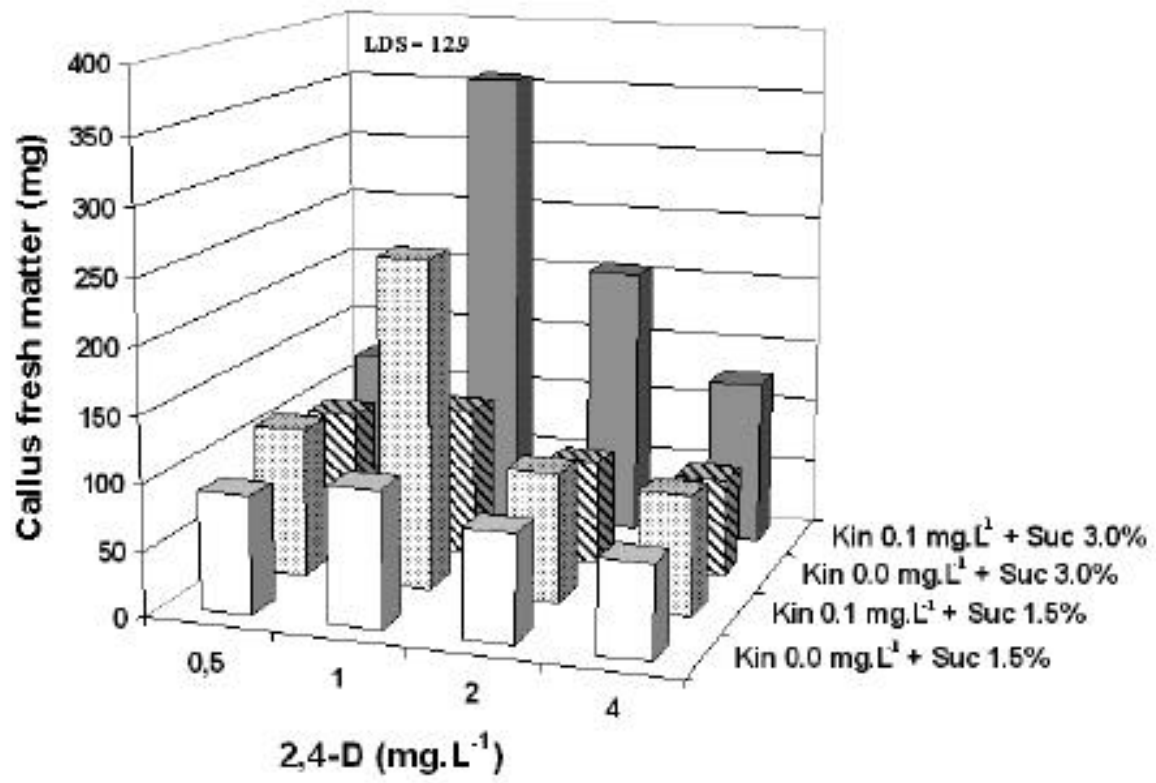

FIGURE 2 - Means of fresh matter of hypocotyl calli subcultived in medium with differents concentration of 2,4$\mathrm{D}$, kinetin (Kin) and sucrose (Suc). 


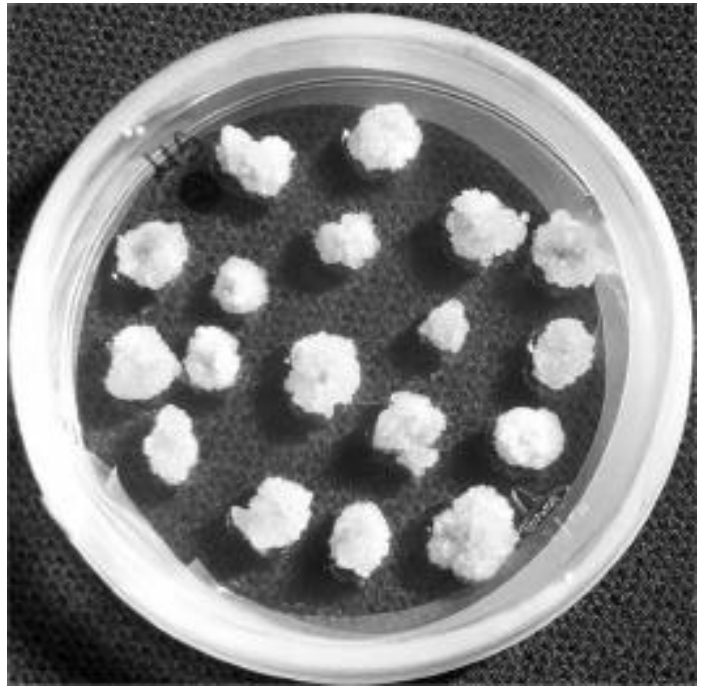

A

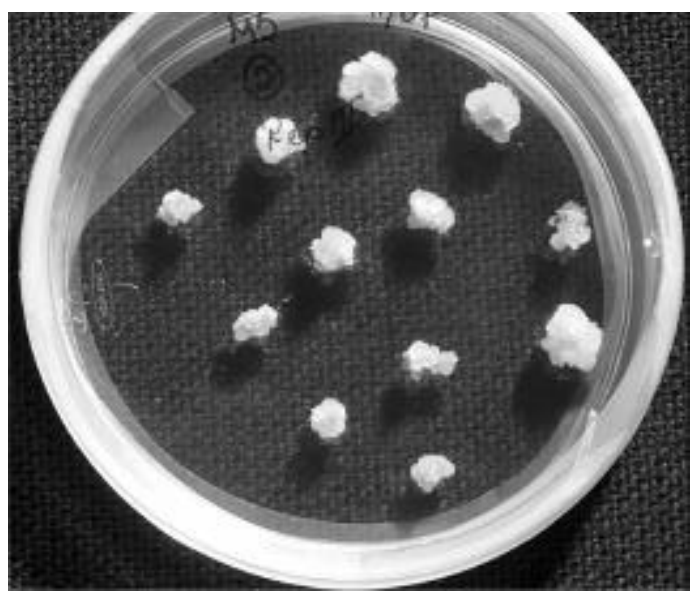

B

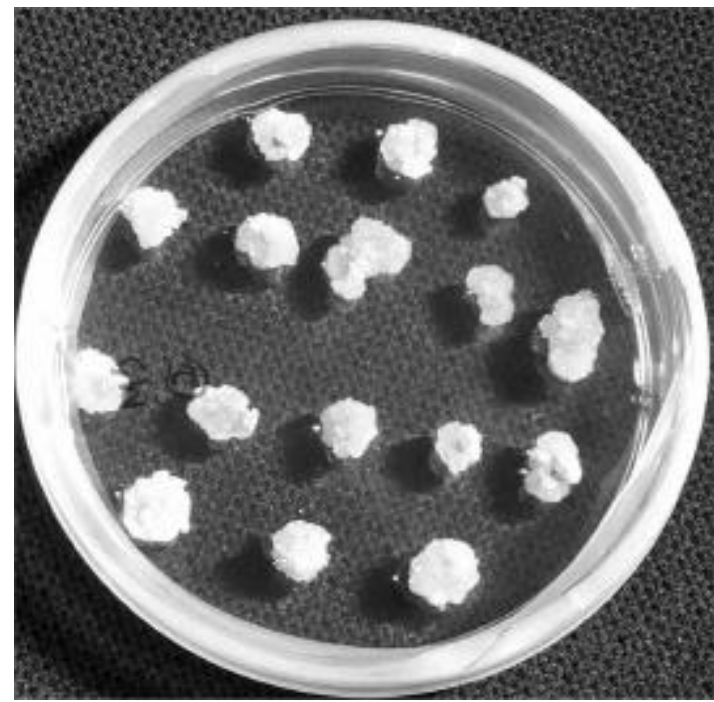

C

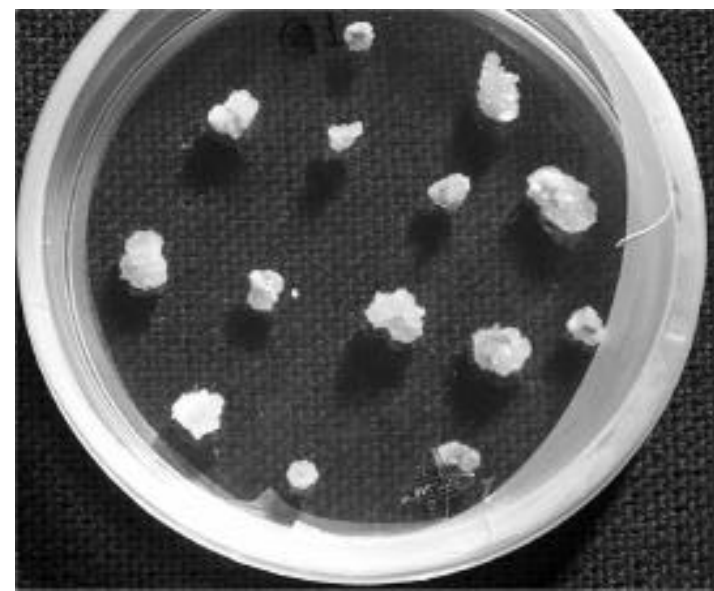

D

Figure 3 - Cotyledon calli subcultived in culture medium with 2,4-D 1.0 mg.L $\mathrm{L}^{-1}$ (A) e $4.0 \mathrm{mg} . \mathrm{L}^{-1}(\mathbf{B})$. Hypocotyl calli subcultived in medium with 2,4-D $2.0 \mathrm{mg} \cdot \mathrm{L}^{-1}(\mathbf{C})$ e $4.0 \mathrm{mg} . \mathrm{L}^{-1}(\mathbf{D})$.

\section{CONCLUSION}

The experimental results obtained in the present work demonstrate that the ideal combination of the concentrations of growth regulators (2,4-D and kinetin) and of sucrose is essential for the induction and subcultive of the cotyledons callus $\left(2.4-\mathrm{D} 1.0 \mathrm{mg} \cdot \mathrm{L}^{-1}\right.$, kinetin $0.1 \mathrm{mg} . \mathrm{L}^{-1}$ and sucrose $3 \%$, for induction as well as for the subculture) and of hypocotyls (2.4-D $1.0 \mathrm{mg} . \mathrm{L}^{-1}, \mathrm{ki}-$ netin $0.1 \mathrm{mg} . \mathrm{L}^{-1}$ and sucrose $3 \%$ - for induction and 2.4-D $2.0 \mathrm{mg} . \mathrm{L}^{-1}$, kinetin $0.1 \mathrm{mg} . \mathrm{L}^{-1}$ and sucrose $3 \%$ for the subculture) of $G$. wightii. It was also demon- strated that the addition of high concentrations of 2,4-D ( $4 \mathrm{mg} . \mathrm{L}^{-1}$ ) to the medium of culture promotes a delay in the development of the calli of cotyledons as well as of hypocotyls.

\section{ACKNOWLEDGMENTS}

This work was supported by grants from the Conselho Nacional de Desenvolvimento Científico e Tecnológico (CNPq), Coordenadoria de Aperfeiçoamento de Pessoal de Nível Superior (CAPES) and Fundação Cearense de Amparo à Pesquisa (FUNCAP).

Ciênc. agrotec., Lavras. V.27, n.6, p.1277-1284, nov./dez., 2003 


\section{REFERENCES}

BERTOLUCCI, S. K. V. Micropropagação, calogênese e abordagem fitoquímica in vivo $\mathrm{e}$ in vitro de Tournefortia cf paniculata Chan. 2000. 79 p. Dissertação (Mestrado em Fitotecnia) - Universidade Federal de Lavras, Lavras, 2000.

DORAN, P. M. Foreing protein production in plant tissue cultures. Current Opinion in Biotechnology, London, v. 11, p. 199-204, 2000.

FRANKLIN, C. I.; DIXON, R. A. Initiation and maintenance of callus and cell suspension culture. In: DIXON, R. A.; GONZALES, R. A. (Eds.). Plant cell culture: a pratical approach. Oxford: Oxford University, 1994. p. 1-26.

GASPAR, T.; KEVERS, C.; PENEL, C.; GREPPIN, H.; REID, D. M.; THORPE, T. A. Plant hormones and plant growth regulators in tissue culture. In Vitro Cellular and Development Biology-Plant, Columbia, v. 32, p. 272-289, 1996.

GEORGE, E. F. Plant propagantion by tissue culture: the technology. 2. ed. [S.1.]: Edington Exegetics, 1996. $1574 \mathrm{p}$.

LITTLE, E. L.; MAGBANUA, Z. V.; PARROTT, W. A. A protocol for repetitive somatic embryogenesis from mature epicotyls of peanut. Plant Cell Report, [S.1.], v. 19, p. 351-357, 2000.
MURASHIGE, T.; SKOOG, F. A revised medium for rapid growth and biossays with tobaco tissue cultures. Physiology Plant, Minneapolis, v. 15, p. 473-479, 1962.

NAGAO, E. O.; PASQUAL, M.; RAMOS, J. D. Efeitos da sacarose e do nitrogênio inorgânico sobre a multiplicação in vitro de brotações de porta-enxerto de citros. Bragantia, Campinas, v. 53, n. 1, p. 25-31, 1994.

PASQUAL, M.; HOFFMANN, A.; RAMOS, J. D. Cultura de tecidos vegetais: tecnologia e aplicações: meios de cultura. Lavras: UFLA/FAEPE, 1998. 127 p.

ROUT, G. R.; DAS, P. Techniques of micropropagation in vitro. In: BOSE, T. K.; MITRA, S. K.; SADHU, M. K.; DAS, P. (Eds.). Propagation of tropical and sub-tropical horticultural crops. Calcutta: Kalyani, 1997. p. 105-16.

ROUT, G. R.; SAMANTARAY, S.; DAS, P. In vitro manipulation and propagation of medicinal plants. Biotechnology Advances, New York, v. 18, p. 91120,2000

SAMOYLOV, V. M.; TUCKER, D. M.; PARROTT, W. A. Soybean (Glycine max (L.) Merrill.) embryogenic cultures: the role of sucrose and total nitrogen content on proliferation. In Vitro Cellular and Development Biology-Plant, Columbia, v. 34, p. 8-13, 1998. 